\title{
ANALISIS KUALITATIF RHODAMIN B PADA KUE KU YANG BEREDAR DI PASAR TRADISIONAL KABUPATEN SLEMAN, YOGYAKARTA
}

\author{
Siti Fatimah, Dian Wuri Astuti, Suryani Dwi Lestari \\ Prodi D3 Analis Kesehatan STIKes Guna Bangsa Yogyakarta; JI.Ringroad Utara Depok \\ Sleman Yogyakarta, telp/Fax: (0274)4477701/(0274)4477702 \\ e-mail: ${ }^{1}$ siti fatimah@gunabangsa.ac.id
}

\begin{abstract}
Background : A food additive used to obtain food products that taste delicious, attractive, durable, easy in its distribution. Food additives that are often used in society is dye. Many fraud by producers to attract consumers such as the use of non-food grade dyes or food grade with doses exceeding the rules. Rhodamine $B$ is a dangerous synthetic dyes are often added to foods as a dye. Kue $\mathrm{Ku}$ is made from a mixture of potatoes, coconut milk, glutinous rice flour, salt, sugar and red dye. The red color on my cake due to the addition of the dye rhodamine B. The use of rhodamine B can cause negative impacts on the health of consumers, thus attracting researchers to examine the presence of rhodamine $B$ dye on my cake circulating in traditional markets Sleman, Yogyakarta.
\end{abstract}

Method : The method is a descriptive study with the aim to describe or illustrate the existence of rhodamine $\mathrm{B}$ on kue $\mathrm{Ku}$ samples circulating in traditional markets Sleman, Yogyakarta. The method used for laboratory test is by thin-layer chromatography.

Results : In this study showed $15,38 \%$ of Kue Ku samples have been investigated positive for rhodamine $\mathrm{B}$.

Conclusion : There dye rhodamine B on Kue Ku circulating in traditional markets Sleman, Yogyakarta.

\section{Keywords : Food dye, rhodamine B, Kue Ku, thin layer chromatography.}

\section{PENDAHULUAN}

Keamanan pangan merupakan kondisi dan upaya yang diperlukan untuk mencegah pangan dari kemungkinan cemaran biologis, kimia yang dapat mengganggu, merugikan dan membahayakan kesehatan manusia. Pangan yang aman serta bermutu dan bergizi tinggi penting bagi pertumbuhan, pemeliharaan, peningkatan kesehatan serta peningkatan kecerdasan masyarakat (Saparinto dan Hidayati, 2006).

Kualitas makanan merupakan keseluruhan sifat-sifat dari makanan yang berpengaruh terhadap penerimaan dari konsumen. Teknologi pengolahan pangan pada saat ini berkembang cukup pesat, termasuk Indonesia. Bahan tambahan makanan digunakan untuk memperoleh produk pangan yang bercita rasa lezat berpenampilan menarik, tahan lama, mudah dalam pengangkutan dan pendistribusiannya. Bahan tambahan makanan yang sering digunakan dalam masyarakat adalah pewarna. Penggunaan pewarna makanan saat ini digunakan dalam upaya memberikan kenampakan visual yang menarik pada makanan. Banyak kecurangan yang dilakukan oleh produsen untuk menarik konsumen seperti penggunaan pewarna non food grade 
atau food grade dengan dosis yang melebihi aturan (Nugraheni, 2013).

Penyalahgunaan bahan tambahan pangan seperti penggunaan pewarna rhodamin $\mathrm{B}$ telah dilarang digunakan. Penggunaan pewarna ini banyak ditemukan pada produk makanan seperti kue-kue basah, saus, sirup, kerupuk dan terasi yang seharusnya pewarna tersebut tidak diperbolehkan untuk makanan. Ciriciri makanan yang mengandung pewarna rhodamin $B$ yaitu warna akan terlihat lebih cerah sehingga tampak menarik, jika dicoba sedikit rasa pahit pada makanan. Metode yang digunakan dalam analisis kualitatif rhodamin $B$ yaitu metode kromatografi lapis tipis (KLT). Prinsip kromatografi lapis tipis dimana teknik pemisahan senyawa berdasarkan fase diam berupa silika gel dan fase gerak berupa pelarut. Keuntungan dari metode ini dimana pemeriksaannya dapat dilakukan dengan cepat, mudah dan menggunakan peralatan yang murah dan sederhana (Sastrohamidjojo, 2005).

Penelitian yang dilakukan oleh Kumawa tahun 2013 di Balai Laboratorium Kesehatan Yogyakarta ditemukan 50\% rainbow cake positif menggunakan rhodamin B (Kumawa, 2013). Hasil pemeriksaan di Balai Laboratorium Kesehatan Yogyakarta pada tanggal 26 November 2014, menunjukkan bahwa $44 \%$ jajanan pasar (kue kukus, aromanis dan kue ku) positif menggunakan rhodamin $B$ yang salah satunya kue ku. Kue ku dibuat dari campuran kentang, santan, tepung ketan, garam, gula dan pewarna merah. Timbul rasa gatal di tenggorokan saat dikonsumsi. Pewarna ini mengandung bahan yang memiliki dampak negatif bahkan dapat menimbulkan kanker (Alsuhendra dan Ridawati, 2013). Kue Ku terdiri dari campuran kacang hijau tanpa kulit yang sudah dihaluskan, gula pasir, santan dan daun pandan. Sebagian warna merah pada kue ku disebabkan karena penambahan pewarna rhodamin $\mathrm{B}$.

Rhodamin B merupakan salah satu pewarna sintetis berbahaya yang sering ditambahkan pada makanan sebagai pewarna, sehingga hal tersebut menarik peneliti untuk melakukan penelitian apakah ada pewarna rhodamin B pada kue ku yang beredar di pasar tradisional Kabupaten Sleman, Yogyakarta. Kriteria kue ku yang dibeli yaitu kue ku dengan warna merah mencolok. Pasar tradisional tersebut meliputi pasar Ngijon, pasar Godean, pasar Balangan, pasar Gamping, pasar Ngino, pasar Sleman, pasar Mlati, pasar Tempel, pasar Prambanan, pasar Kalasan, pasar Maguwo, pasar Gentan, pasar Turi, pasar Tanjung Tirto, pasar Jangkang, pasar Pakem dan pasar Banjar Harjo.

\section{METODE PENELITIAN}

Penelitian ini merupakan penelitian deskriptif dengan tujuan mendeskripsikan atau menggambarkan ada tidaknya rhodamin B pada sampel kue ku yang beredar di pasar tradisional Kabupaten Sleman, Yogyakarta. Metode yang digunakan untuk uji laboratorium yaitu dengan kromatografi lapis tipis. Penelitian dilakukan pada pedagang yang menjual kue ku yang beredar di pasar tradisional yang berada di Kabupaten Sleman, Yogyakarta kemudian diuji di Balai Laboratorium Kesehatan Yogyakarta pada bulan Februari 2015.

Bahan : Kue ku

Reagensia : $\mathrm{NH}_{4} \mathrm{OH} 2 \%, \mathrm{NH}_{4} \mathrm{OH} 10 \%$ Asam asetat 10\%, Aquades, Etanol Metanol dan n-butanol, Standar Rhodamin $\mathrm{B}$

Peralatan: Satu set alat kromatografi lapis tipis, neraca, waterbath, alat-alat gelas, kertas lakmus, cawan porselin, benang wool

\section{Tahap Pelaksanaan Penelitian}

\section{a. Pembuatan standar rhodamin $B$} 25,00 mg bubuk rhodamin B ditimbang, kemudian dilarutkan dalam $35 \mathrm{~mL}$ methanol

\section{b. Proses ekstraksi}

1) Sampel kue ku yang bewarna merah ditimbang sebanyak 5 gram dan dimasukkan ke dalam erlemenyer kemudian ditambahkan $\mathrm{NH}_{4} \mathrm{OH} 2 \%$ dalam alkohol $70 \%$ hingga sampel kue ku terendam seluruhnya 
2) Residu yang didapatkan dipindahkan kedalam cawan porselin, kemudian diasamkan dengan penambahan asam asetat $10 \%$ hingga bereaksi asam yang ditandai dengan perubahan warna biru menjadi merah pada kertas lakmus

3) Benang wool ditambahkan secukupnya, dikeringkan di atas water bath sampai kering selanjutnya benang wool dicuci dengan aquades

4) Benang wool dimasukkan ke dalam cawan porselin, ditambahkan $5 \mathrm{~mL}$ $\mathrm{NH}_{4} \mathrm{OH} 10 \%$ sampai warna larut, benang wool dibuang dan cairan dikeringkan di atas water bath sampai kering

5) Residu dilarutkan dengan metanol dan siap untuk diteteskan pada plat KLT

\section{c. Analisis mengunakan kromatografi lapis tipis}

1) Plat KLT disiapkan, chamber dan bahan yang akan digunakan

2) $20 \mu \mathrm{l}$ sampel ditotolkan dan standar pembanding rhodamin $\mathrm{B}$ dengan tabung mikrokapiler pada plat KLT dengan jarak $2 \mathrm{~cm}$ dari bagian bawah plat dan jarak antar noda $2 \mathrm{~cm}$ biarkan hingga kering

3) Eluen dibuat dengan campuran $n$ butanol : etanol : aquades (20:12:5) dengan total volume $37 \mathrm{~mL}$, kemudian dimasukkan dalam chamber

4) Chamber dijenuhkan menggunakan kertas saring, jika kertas saring sudah basah menandakan chamber sudah terjenuhkan oleh pelarut

5) Plat KLT dimasukkan ke dalam chamber dan diamati

6) Pelarut dibiarkan merambat dengan jarak rambat elusi $10 \mathrm{~cm}$ dari totolan

7) Setelah mencapai jarak elusi, plat KLT dikeluarkan dan dikeringkan

8) Hasil bercak warna yang timbul pada plat KLT dilihat dibawah sinar ultraviolet kemudian tandai bercak menggunakan pensil

9) Nilai faktor retensi (Rf)

\section{HASIL DAN PEMBAHASAN}

Penelitian yang berjudul "Analisis Kualitatif Rhodamin B Pada Kue Ku Yang Beredar Di Pasar Tradisional Kabupaten Sleman, Yogyakarta" telah dilakukan pada tanggal 6-14 Februari 2015 di Balai Laboratorium Kesehatan Yogyakarta. Berdasarkan hasil penelitian yang telah dilakukan menggunakan metode kromatografi lapis tipis, didapatkan hasil pemeriksaan kue ku positif mengandung rhodamin B sebesar 15,38\% dan hasil negatif tidak mengandung rhodamin $B$ sebesar $84,62 \%$.

Identifikasi rhodamin B pada kue ku yang beredar di pasar tradisional Kabupaten Sleman, Yogyakarta menggunakan metode KLT. Terlebih dahulu dilakukan survei sampel pada pedagang kue ku yang beredar di pasar tradisional Kabupaten Sleman, Yogyakarta dan dilakukan pembelian sampel pada 26 pedagang yang menjual kue ku dengan kriteria warna merah mencolok, kemudian dilakukan pemberian label pada setiap sampelnya. Sebanyak 26 sampel kue ku ditindaklanjuti dengan melakukan pemeriksaan di Balai Laboratorium Kesehatan Yogyakarta. Pengkodean terhadap sampel yang akan diteliti dilakukan untuk mempermudah dalam proses identifikasi. Kode diberikan berdasarkan nomor urut sampel yang masuk di Balai Laboratorium Kesehatan Yogyakarta.

Identifikasi kue ku metode KLT terlebih dahulu dengan melakukan proses ekstraksi. Bagian kulit dari kue ku yang berwarna merah ditimbang sebanyak 5 gram dimasukkan ke dalam erlemenyer dan diberi kode sesuai sampel. Setiap sampel kue ku ditambahkan dengan larutan $\mathrm{NH}_{4} \mathrm{OH} 2 \%$, tujuan penambahan larutan $\mathrm{NH}_{4} \mathrm{OH} 2 \%$ yaitu untuk melarutkan pewarna rhodamin $\mathrm{B}$ pada sampel kue ku sehingga warna merah akan terpisah, kemudian dilakukan pendiaman selama \pm 1 jam. Setelah didiamkan selama \pm 1 jam cairan yang bewarna merah pada sampel dipindahkan ke dalam cawan porselin, kemudian ditambahkan asam asetat 10\%. Penambahan asam asetat $10 \%$ dilakukan dengan tujuan untuk menghilangkan zat pengganggu yang terdapat pada sampel 
kue ku dan sebagai pengatur keasaman dengan menambahkan kertas lakmus biru ke dalam sampel. Sampel bersuasana asam yang ditandai dengan terjadi perubahan warna pada kertas lakmus biru menjadi merah.

Sampel yang telah bersuasana asam ditambahkan benang wool, kemudian dikeringkan dengan waterbath hingga kering. Benang wool berfungsi untuk mengikat zat warna rhodamin B agar menempel dan berikatan dengan benang wool, pengeringan bertujuan untuk menghilangkan cairan lain yang terdapat pada sampel selain pewarna yang terkandung pada benang wool. Benang wool yang terdapat pada sampel yang telah dikeringkan diambil, kemudian dicuci dengan aquades untuk membersihkan dari sisa-sisa kotoran yang ikut bercampur dalam cairan. Benang wool dimasukkan ke dalam cawan porselin dan ditambahkan $\mathrm{NH}_{4} \mathrm{OH} 10 \%$ dengan tujuan untuk melarutkan zat warna yang terserap pada benang wool, kemudian cairan dikeringkan dalam waterbath untuk mendapatkan residu. Residu kemudian dilarutkan dengan metanol dan siap ditotolkan pada plat KLT, penambahan metanol berfungsi untuk mengencerkan zat warna yang terkandung pada sampel setelah proses pengeringan

Residu yang didapat dari proses pengeringan dilarutkan dengan metanol, kemudian ditotolkan pada fase diam berupa silika gel dengan fase gerak yang terdiri dari campuran n-butanol : etanol : aquades dengan perbandingan $(20: 12$ : 5). Pemilihan fase gerak didasarkan pada sifat fisika dan kimia yang dimiliki rhodamin B yaitu dapat larut dalam air dan menghasilkan fluoresensi bewarna merah. Residu yang telah dilarutkan dengan metanol ditotolkan pada plat KLT secara perlahan untuk mendapatkan hasil yang baik dengan jarak $2 \mathrm{~cm}$ dari bagian bawah plat dan jarak antar noda $2 \mathrm{~cm}$.

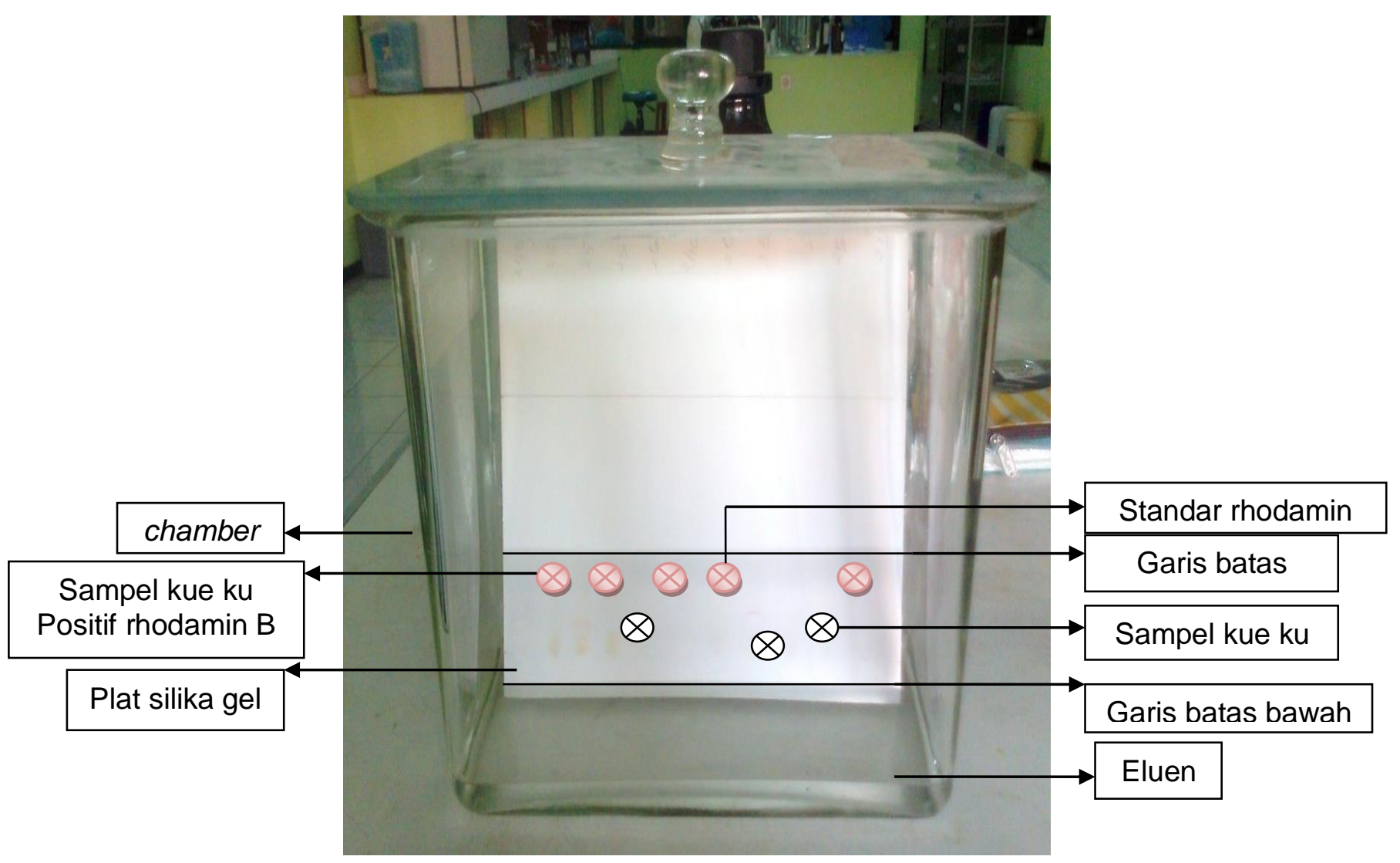

Gambar 1. Proses pemisahan rhodamin B metode KLT 
Fase gerak yang akan digunakan dijenuhkan terlebih dahulu dengan cara memasukkan kertas saring ke dalam campuran $\mathrm{n}$-butanol : etanol : aquades yang terdapat di dalam chamber, jika kertas saring sudah basah menandakan chamber sudah terjenuhkan oleh pelarut. Tujuan penjenuhan untuk menghomogenkan campuran dan menghilangkan uap air/gas lain pada fase penyerap yang akan menghalangi laju eluen. Plat KLT dimasukkan pada chamber yang sudah jenuh, kemudian ditunggu hingga eluen begerak mencapai garis batas. Hasil pemisahan rhodamin B dengan metode KLT terdapat pada gambar 1.

Berdasarkan hasil penelitian yang telah dilakukan menggunakan metode kromatografi lapis tipis, didapatkan hasil pemeriksaan sampel kue ku positif mengandung rhodamin B sebesar 15,38\% dan hasil negatif tidak mengandung rhodamin B sebesar $84,62 \%$ seperti yang ditunjukkan pada gambar 2 .

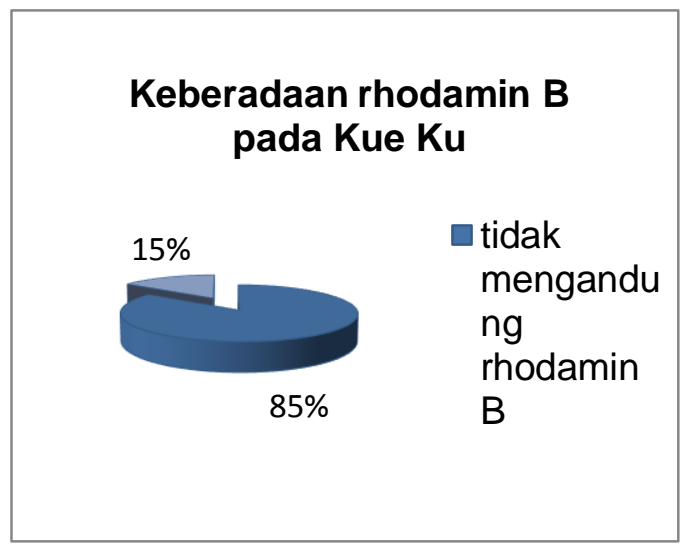

Gambar 2. Persentase keberadaan rhodamin B pada kue ku

Hasil tersebut bila dibandingkan dengan penelitian (Kumawa, 2013) dengan judul "Identifikasi Rhodamin B pada Rainbow Cake dengan Metode Kromatografi Lapis Tipis di Kabupaten Sleman, Yogyakarta". Hasil penelitian menunjukkan $50 \%$ sampel rainbow cake positif mengandung rhodamin B. Hal ini mengindikasikan bahwa sebagian besar produsen makanan telah mengetahui penggunaan pewarna makanan yang tepat, dapat dilihat dari penurunan persentase penyalahgunaan pewarna rhodamin B pada makanan terutama di Kabupaten Sleman, Yogyakarta.

Rhodamin B tidak hanya disebabkan oleh senyawa organik, tetapi dapat disebabkan oleh senyawa anorganik yang terdapat pada rhodamin B. Rhodamin B bila terkontaminasi oleh senyawa anorganik seperti timbal dan arsen menjadikan pewarna ini berbahaya bila dikonsumsi. Rhodamin B bersifat senyawa halogen yang berasal dari struktur rhodamin $\mathrm{B}$ yaitu klorin $(\mathrm{Cl})$, dimana sifat halogen yaitu mudah bereaksi atau memiliki reaktivitas yang tinggi. Rhodamin B akan mencapai kestabilan didalam tubuh dengan cara berikatan dengan senyawa-senyawa yang ada didalam tubuh sehingga pada akhirnya memicu kanker pada manusia. Ion klorin (Cl) pada suhu kamar akan membentuk gas beracun yang tanpa sengaja terhirup oleh manusia akan menyebabkan kanker. Rhodamin $\mathrm{B}$ memiliki senyawa $\mathrm{CH}_{3}-\mathrm{CH}_{3}$ yang bersifat radikal bebas sehingga didalam tubuh akan berikatan dengan dengan protein, lemak dan DNA didalam tubuh manusia. Keberadaan rhodamin B pada makanan dapat menimbulkan efek kronis apabila dikonsumsi dalam jangka waktu lama yang menyebabkan kanker (Cahyadi, 2012). Pencegahan dalam memilih produk makanan dapat dilakukan dengan cara:

1. Lebih teliti dalam membeli produk makanan seperti menghindari jajanan yang berwarna terlalu mencolok terutama jajanan yang dijual di pinggir jalan.

2. Mengenali kode registrasi produk seperti produk makanan yang sudah terdaftar di Badan POM atau untuk pangan industri rumah tangga yang sudah terdaftar di Dinas Kesehatan.

3. Tidak membeli produk makanan yang tidak mencantumkan informasi kandungannya pada bagian label.

\section{KESIMPULAN DAN SARAN}

\section{A.Kesimpulan}

Berdasarkan hasil penelitian "Analisis kualitatif Rhodamin B Pada Kue Ku Yang Beredar Di Pasar Tradisional Kabupaten 
Sleman, Yogyakarta" yang telah dilakukan, dapat diambil kesimpulan yaitu $15,38 \%$ sampel kue ku positif mengandung rhodamin $\mathrm{B}$.

\section{B.Saran}

Setelah dilakukan evaluasi pada penelitian ini, penulis menyampaikan beberapa pesan bagi pembaca yang tertarik untuk melanjutkan penelitian ini. Perlu dilakukan penelitian lebih lanjut untuk mengetahui kandungan bahan tambahan lain seperti pengawet dan sakarin yang terdapat pada kue ku.

\section{DAFTAR PUSTAKA}

Alsuhendra., Ridawati., 2013, Bahan Toksik Dalam Makanan, PT Remaja Rosdakarya Offset, Bandung : Hal. 17, 134-135, 241-242.
Cahyadi, W., 2012, Analisis dan Aspek Kesehatan Bahan Tambahan Pangan, terbitan ke-3, PT Bumi Aksara Jakarta : Hal. 1-2, 61.

Kumawa, P., 2013, "Identifikasi Rhodamin B Pada Rainbow Cake Dengan Kromatografi Lapis Tipis Di Kabupaten Sleman Yogyakarta", Karya Tulis IImiah STIKES Guna Bangsa Yogyakarta.

Nugraheni, M., 2013, Pewarna Alami Sumber dan Aplikasinya pada Makanan \& Minuman, Graha IImu, Yogyakarta : Hal 1.

Saparinto, C., Hidayati, D., 2006, Bahan Tambahan Pangan, Penerbit Kanisius, Yogyakarta : Hal. 55

Sastrohamidjojo, H., 2005, Kromatografi, Liberty Yogyakarta : Hal. 5, 35. 